\title{
'NC-Sunshine' and 'NC-Stratford' Slicing Cucumber Hybrids
}

Todd C. Wehner

Department of Horticultural Science, North Carolina State University, Raleigh, NC 27695-7609

Additional index words. Cucumis sativus, germplasm, processing cucumber, vegetable breeding

Four slicing (fresh-market) cucumber inbreds (NC-58, NC-59, NC-62, and NC-63) and two hybrids ('NC-Stratford' and 'NCSunshine'), were developed at North Carolina State University. As with most cucumber cultivars released from N.C. State, 'NC-Stratford' and 'NC-Sunshine' were named for places around the state. 'NC-Stratford' is the $\mathrm{F}_{1}$ of $\mathrm{NC}-58 \times \mathrm{NC}-59$, and 'NC-Sunshine' is the $\mathrm{F}_{1}$ of NC-62 $\times$ NC-63. The four inbreds have been self-pollinated past the $\mathrm{S}_{12}$ generation, and were developed from the North Carolina Elite Determinate Slicer (NCEDS) population. The NCEDS population was developed by 1) crossing elite hybrids and inbreds with 'Spacemaster' dwarf-determinate inbred in 1983; 2) intercrossing the dwarf-determinate $\mathrm{F}_{2}$ with dwarf-determinate hybrids and inbreds; and 3 ) intercrossing the $F_{1}$ to form a population for use in recurrent selection. Selection methods were developed that optimized gain for yield and other traits (Wehner, 1989). Selection in the NCEDS population was for fruit shape, and total, marketable and early yield in the spring season, as well as for resistance to foliar fungal diseases in the summer season. The main diseases in the summer were anthracnose [Colletotrichum orbiculare (Berk. and Curt.) Arx] and gummy stem blight [Didymella bryoniae (Auersw.) Rehm]. In addition to yield, earliness, quality and disease resistance, the cucumber families were selected for production of sufficient seeds to plant the test and intercross plots, rapid seed germination and emergence, rapid vine growth and flowering, and proper fruit type.

\section{Origin}

The NC-58, NC-59, NC-62, and NC-63 inbreds, and 'NC-Stratford' and 'NC-Sunshine' hybrid slicing cucumbers were developed from crosses of dwarf-determinate 'Spacemaster' with elite slicing cucumbers having high yield, earliness, fruit quality, and disease resistance (Fig. 1). 'Spacemaster'was used to introduce the dwarf-determinate plant type into elite inbreds and hybrids: 'Spacemaster', 'Marketmore 80F', 'Poinsett 76F', 'Dasher', 'Pacer', 'Sprint 440', and Sakata Gyn 7. All of the parents had good yield, earliness, quality, and disease resistance, along with American slicing type fruit. All of

Received for publication 30 Dec. 2004. Accepted for publication 3 Mar. 2005. The use of trade names in this publication does not imply endorsement by the NCARS of the products named, or criticism of similar ones not mentioned. Thanks to Tammy L. Ellington for technical assistance.
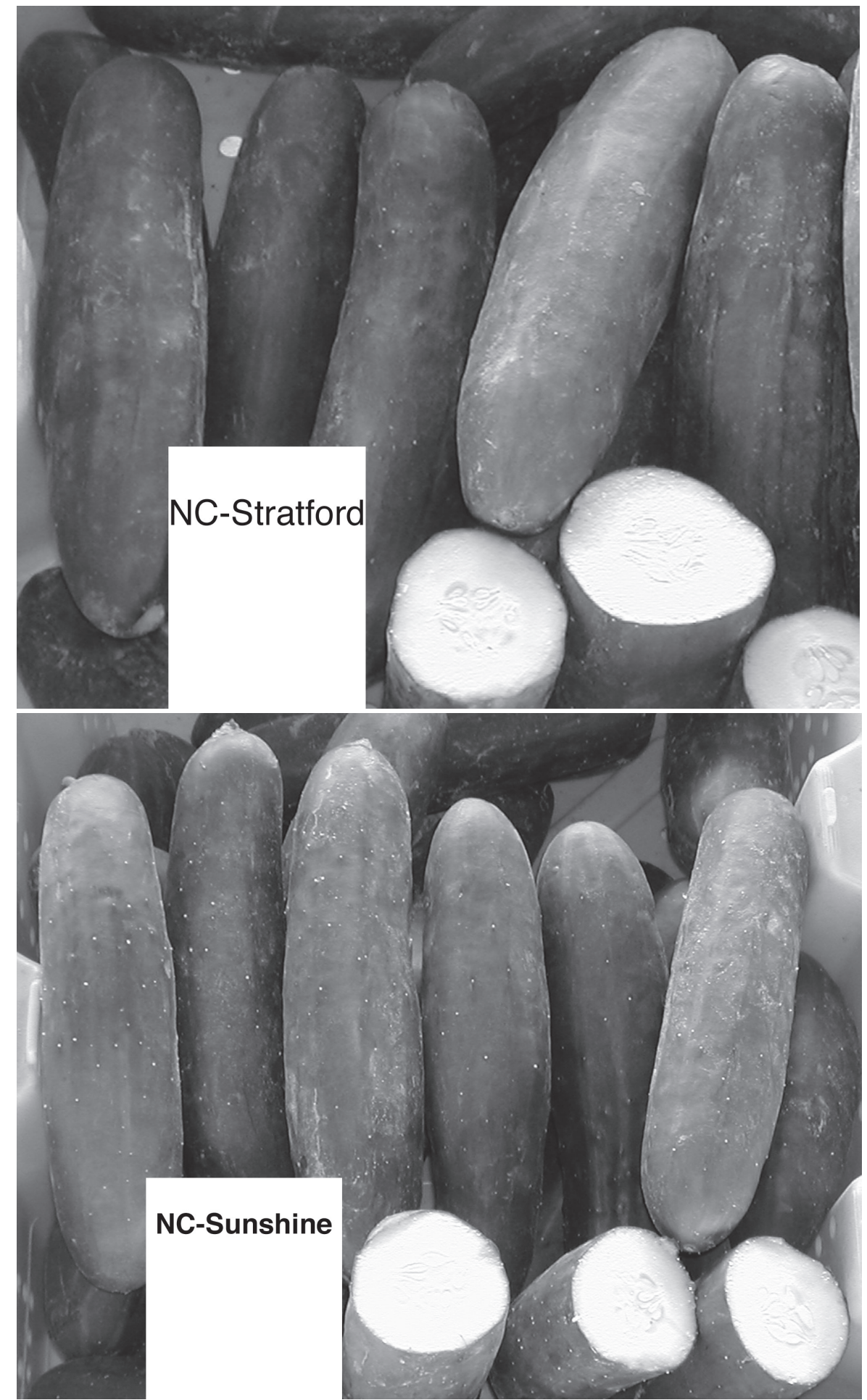

Fig. 1. Fruit of 'NC-Stratford' (top) and 'NC-Sunshine' (bottom) hybrid slicing cucumbers. 
the parents except 'Pacer' and 'Spacemaster' were gynoecious. In addition, 'Sprint 440' had high yield, 'Marketmore 80F' had high quality, 'Poinsett 76F' had high disease resistance, and 'Dasher', 'Pacer', and Sakata Gyn 7 had high all-around performance. The inbreds and hybrids were crossed with 'Spacemaster', the F selfpollinated, and the $\mathrm{F}_{2}$ selected for dwarf-determinate type (Fig. 1). The dwarf-determinate $\mathrm{F}_{2}$ were backcrossed to the elite gynoecious inbreds and hybrids, the $\mathrm{BC}_{1}$ self pollinated, and 88 plots of the $\mathrm{BC}_{1} \mathrm{~S}_{1}$ intercrossed in a field isolation block with 5 plots each of dwarf-determinate 'Spacemaster' and 'Bush Champion'. That intercross block was used as the cycle 0 of the North Carolina Elite Determinate Slicer (NCEDS) population. The NCEDS population was then improved for disease resistance, yield, earliness, and fruit quality through 9 cycles of recurrent selection.

The population was improved by testing in the spring season followed by intercrossing the best families in isolation blocks in the summer season. Once-over harvest was simulated by spraying the foliage with paraquat $\left(1,1^{\prime}\right.$-dimethyl-4,4'-bipyridinium ion) at $0.6 \mathrm{~kg} \cdot \mathrm{ha}^{-1}$ when the checks had about $10 \%$ oversized fruit by number (Wehner et al., 1984). Oversized fruit exceeded $60 \mathrm{~mm}$ in diameter. Half-sib families were evaluated for five traits: total yield (number of fruit per plot), early yield (number of oversized fruit per plot), marketable yield (total yield minus crooked and nubbin fruit), fruit shape rating $(1=$ poor to $9=$ excellent $)$, and a simple weighted index (Wehner, 1982). The simple weighted index was calculated as $\mathrm{SWI}=0.2($ total yield $) / 2+0.3($ early yield $)+$ $0.2(\%$ marketable yield) $/ 10+0.3$ (fruit shape) . Total yield was divided by 2 and percentage marketable yield was divided by 10 to give them the same range (1 to 9) as the other traits. Each trait was then given a weight $(20 \%$ or $30 \%)$ to reflect its importance in the breeding program. SWI was weighted (70\%) toward yield traits, but with significant emphasis on quality since shape rating $(30 \%)$ is related to fruit appearance, and marketable yield (20\%) accounts for crooked and nubbin fruit.

Inbred lines were evaluated in trials for yield, earliness, fruit quality, and disease resistance using optimized trialing methods (Wehner, 1987). Recommended cultural practices (summarized by Schultheis, 2000) were used throughout the experiments. Monoecious inbred 'Poinsett 76' was planted in field border rows and end tiers as a pollenizer, and to provide border competition for the trial. Irrigation was applied when needed for a total of 25 to $40 \mathrm{~mm}$ per week (including rainfall). Fertilizer was incorporated at a rate of $90-39-74 \mathrm{~kg} \cdot \mathrm{ha}^{-1}(\mathrm{~N}-\mathrm{P}-\mathrm{K})$ before planting, with an additional $34 \mathrm{~kg} \mathrm{~N} / \mathrm{ha}$ applied at the vine-tip-over (four to six true leaf) stage. Herbicide [Curbit, ethalfluralin, $N$-ethyl- $N-(2-$

Table 1. Horticultural performance (yield, earliness, quality, and disease resistance) of new dwarf-determinate slicing cucumber hybrids (NC-Stratford and NCSunshine) compared with standard cultivars (all others). Data are summarized over three replications and six harvests for two crop production seasons (spring and summer) at the Horticultural Crops Research Station near Clinton, N.C., for 2001 through 2003.

\begin{tabular}{|c|c|c|c|c|c|c|c|c|c|}
\hline Population & $\begin{array}{c}\text { Total } \\
\text { yield } \\
\left(\mathrm{Mg} \cdot \mathrm{ha}^{-1}\right)\end{array}$ & $\begin{array}{c}\text { Early } \\
\text { yield }^{y} \\
(\%)\end{array}$ & $\begin{array}{c}\text { Cull } \\
\text { yield } \\
(\%)\end{array}$ & $\begin{array}{c}\text { Fruit } \\
\text { shape }^{\mathrm{x}}\end{array}$ & $\begin{array}{c}\text { Fruit } \\
\text { color }^{w}\end{array}$ & $\begin{array}{l}\text { Seed } \\
\text { cell }^{\mathrm{v}}\end{array}$ & $\begin{array}{l}\text { Length } \\
(\mathrm{mm})\end{array}$ & $\begin{array}{l}\text { Length } \\
\text { to diam } \\
\text { ratio }\end{array}$ & $\begin{array}{c}\text { Anthracnose } \\
\text { rating }\end{array}$ \\
\hline \multicolumn{10}{|l|}{$2001^{\mathrm{t}}$} \\
\hline NC-Stratford & 41.4 & 67 & 41 & 6.3 & 8.3 & 6.8 & 198 & 3.6 & 3.8 \\
\hline NC-Sunshine & 39.1 & 63 & 48 & 6.8 & 8.6 & 7.1 & 201 & 3.8 & 5.3 \\
\hline Marketmore 85 & 24.4 & 51 & 39 & 7.9 & 8.6 & 7.8 & 201 & 4.0 & 7.8 \\
\hline $\operatorname{LSD}(5 \%)$ & 13.6 & 15 & 11 & 0.9 & 0.6 & 0.9 & 8 & 0.2 & 2.3 \\
\hline \multicolumn{10}{|l|}{ Spring $2002^{\mathrm{s}}$} \\
\hline NC-Stratford & 49.4 & 31 & 33 & 6.3 & 8.0 & 6.3 & 246 & 4.0 & 1.7 \\
\hline NC-Sunshine & 39.3 & 33 & 36 & 7.0 & 8.7 & 7.7 & 218 & 3.8 & 3.0 \\
\hline Dasher II & 34.5 & 18 & 26 & 8.0 & 7.7 & 6.3 & 229 & 4.1 & 1.7 \\
\hline Poinsett 76 & 27.0 & 0 & 18 & 8.0 & 8.7 & 7.7 & 187 & 3.3 & 1.3 \\
\hline $\operatorname{LSD}(5 \%)$ & 16.5 & 14 & 13 & 2.0 & 1.3 & 1.5 & 17 & 0.4 & 1.6 \\
\hline \multicolumn{10}{|c|}{ Summer 2002 (hot, dry conditions) } \\
\hline NC-Stratford & 3.4 & 70 & 55 & 7.0 & 8.0 & 6.7 & 157 & 3.5 & 5.2 \\
\hline NC-Sunshine & 1.9 & 19 & 43 & 5.7 & 7.3 & 7.3 & 176 & 3.6 & 4.3 \\
\hline Dasher II & 6.7 & 44 & 33 & 6.7 & 8.0 & 7.0 & 168 & 3.5 & 2.7 \\
\hline Intimidator & 5.1 & 57 & 42 & 6.3 & 7.7 & 7.0 & 169 & 3.6 & 1.0 \\
\hline $\operatorname{LSD}(5 \%)$ & 3.9 & 40 & 29 & 1.2 & 0.9 & 2.1 & 26 & 0.4 & 1.3 \\
\hline \multicolumn{10}{|l|}{ Spring 2003} \\
\hline NC-Stratford & 35.9 & 53 & 42 & 5.7 & 6.7 & 6.3 & 213 & 3.9 & 2.3 \\
\hline NC-Sunshine & 30.6 & 52 & 36 & 6.0 & 8.3 & 7.3 & 204 & 3.7 & 2.7 \\
\hline Dasher II & 22.8 & 42 & 27 & 5.7 & 6.0 & 6.7 & 192 & 3.9 & 2.3 \\
\hline Intimidator & 26.5 & 61 & 36 & 5.7 & 8.0 & 5.0 & 193 & 3.6 & 2.0 \\
\hline Cherokee & 30.4 & 62 & 46 & 5.7 & 6.3 & 5.3 & 200 & 3.8 & 1.7 \\
\hline Poinsett 76 & 25.6 & 20 & 30 & 5.7 & 6.3 & 6.0 & 180 & 3.5 & 1.0 \\
\hline Marketmore 86 & 24.8 & 36 & 42 & 5.3 & 7.3 & 7.0 & 201 & 3.6 & 2.0 \\
\hline Marketmore 76 & 20.2 & 24 & 29 & 5.0 & 6.3 & 5.3 & 192 & 3.6 & 2.3 \\
\hline Ashley & 23.0 & 31 & 35 & 5.0 & 6.0 & 4.3 & 200 & 3.8 & 1.3 \\
\hline $\operatorname{LSD}(5 \%)$ & 9.6 & 15 & 13 & 2.0 & 1.4 & 1.7 & 17 & 0.4 & 1.7 \\
\hline \multicolumn{10}{|l|}{ Summer 2003} \\
\hline NC-Stratford & 25.1 & 49 & 38 & 6.3 & 7.7 & 7.3 & 198 & 3.7 & 3.7 \\
\hline NC-Sunshine & 13.6 & 39 & 19 & 5.7 & 8.3 & 7.3 & 191 & 3.8 & 6.0 \\
\hline Dasher II & 11.3 & 25 & 25 & 6.0 & 6.0 & 8.0 & 187 & 3.7 & 3.7 \\
\hline Intimidator & 14.6 & 40 & 48 & 5.3 & 6.7 & 7.0 & 198 & 4.2 & 4.3 \\
\hline Cherokee & 21.5 & 38 & 47 & 4.7 & 6.0 & 6.7 & 183 & 3.6 & 4.0 \\
\hline Poinsett 76 & 10.4 & 1 & 32 & 5.3 & 7.0 & 5.7 & 165 & 3.5 & 1.3 \\
\hline Marketmore 86 & 13.1 & 8 & 28 & 6.0 & 7.3 & 7.0 & 186 & 3.6 & 5.0 \\
\hline Marketmore 76 & 22.5 & 44 & 49 & 5.7 & 7.0 & 7.0 & 197 & 4.0 & 5.3 \\
\hline Ashley & 10.5 & 13 & 32 & 5.0 & 5.7 & 7.0 & 185 & 3.7 & 4.0 \\
\hline $\operatorname{LSD}(5 \%)$ & 11.0 & 27 & 26 & 1.9 & 1.7 & 1.2 & 19 & 0.4 & 2.3 \\
\hline
\end{tabular}

${ }^{\mathrm{z}}$ Weight of all grades including oversized and cull fruit.

ypercent of the six-harvest yield that occurred in the first two harvests.

${ }^{x}$ Fruit shape was rated 1 to 9 ( 1 to 3 = pointed, crooked, constricted; 4 to $6=$ tapered, curved, necked; 7 to $9=$ blocky, straight, cylindrical).

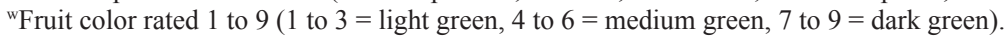

'Seedcell size rated 1 to 9 ( 1 to $3=$ large, 4 to $6=$ medium, 7 to $9=$ small $)$.

"Disease rating taken 1 week after the final harvest, and rated 0 to $9(0=$ none, 1 to $2=$ trace, 3 to $4=$ slight, 5 to $6=$ moderate, 7 to $8=$ severe, $9=$ dead $)$.

${ }^{\mathrm{t}}$ Mean of four environments: spring, summer, Clinton field 1, Clinton field 2.

${ }^{\mathrm{s}}$ All four cultivars had a dwarf-determinate rating of 4 to 5 ( 1 to $3=$ dwarf, 4 to $6=$ medium dwarf, 7 to $9=$ tall), and a gynoecious rating of 5 to 6 ( 1 to $3=$ androecious, 4 to $6=$ monoecious, 7 to $9=$ gynoecious). 
Table 2.

\begin{tabular}{|c|c|c|}
\hline Year & Season & Location-Event \\
\hline$\overline{1983}$ & Fall & Greenhouse-Cross inbreds, hybrids with Spacemaster \\
\hline 1984 & Spring & Greenhouse- $F_{1}$ (self all) \\
\hline 1984 & Fall & Greenhouse- $F_{2}$ (backcross elite parents $\mathrm{x}$ det F2) \\
\hline 1985 & Spring & $\begin{array}{l}\text { Greenhouse- }-\mathrm{BC}_{1} \text { (self all); intercross BC1S1 ( } 88 \text { plots) } \\
\text { with Bush Champion, Spacemaster (10 plots) }\end{array}$ \\
\hline 1985 & Summer & Field-Begin population improvement $\mathrm{CO}$ \\
\hline 1995 & Summer & Field-End population improvement $\mathrm{C} 9$ \\
\hline 1996 & Spring & Greenhouse-384 HS (test scab, anth, PM, self 1 plant each) \\
\hline 1996 & Summer & Greenhouse- $346 \mathrm{~S}_{1}$ (test scab, anth, PM, self 1 plant each) \\
\hline 1996 & Summer & Field-352 S1 (test gyn, det, yield, earliness, quality) \\
\hline 1996 & Fall & Greenhouse- $-36 \mathrm{~S}_{2}$ (test scab, anth, PM, self 1 plant each) \\
\hline 1997 & Spring & Greenhouse- $22 \mathrm{~S}_{3}$ (test scab, anth, PM, self 1 plant each) \\
\hline 1997 & Summer & Greenhouse- $-77 \mathrm{~S}_{4}^{3}$ (test scab, anth, PM, self 1 plant each) \\
\hline 1997 & Summer & Field-77 S (test gyn, det, yield, earliness, quality) \\
\hline 1997 & Fall & Greenhouse- $-42 \mathrm{~S}_{5}$ (test scab, anth, PM, self 1 plant each) \\
\hline 1998 & Spring & Greenhouse- $-73 \mathrm{~S}_{6}$ (test scab, anth, PM, self 1 plant each) \\
\hline 1998 & Summer & Greenhouse- $-96 \mathrm{~S}_{7}$ (test scab, anth, PM, self 1 plant each) \\
\hline 1998 & Summer & Field-77 S7 (test gyn, det, yield, earl, quality) \\
\hline 1999 & Spring & Greenhouse- $-75 \mathrm{~S}_{8}$ (test scab, anth, PM, self 1 plant each) \\
\hline 1999 & Summer & Field - 146 S9 (test gyn, det, yield, earliness, quality) \\
\hline 1999 & Fall & Greenhouse-13 $\mathrm{S}_{9}$ (self, cross 7 gyn x 6 mon) \\
\hline 2000 & Spring & Greenhouse-12 $\mathrm{S}_{10}$ (self, cross 7 gyn x 6 mon) \\
\hline 2000 & Summer & Greenhouse- $49 \mathrm{~S}_{11}$ (self 7 gyn, 42 mon) \\
\hline 2000 & Summer & Field-42 F1 (test gyn, det, yield, earliness, quality) \\
\hline 2000 & Fall & Greenhouse-11 $\mathrm{S}_{11}$ (make 11 inbreds, 12 hybrids) \\
\hline 2001 & Fall & Greenhouse- $-6 \mathrm{~S}_{11}$ (make 8 inbreds, 4 hybrids) \\
\hline 2002 & Spring & Greenhouse- $8 \mathrm{~S}_{12}$ (make 4 inbreds, 2 hybrids) \\
\hline
\end{tabular}

methyl-2-propenyl)-2,6-dinitro-4-(trifluorom ethyl)benzenamine] and insecticide (Sevin, carbaryl, 1-NaphthylN-methylcarbamate) were applied at recommended rates.

In the Spring 1996 greenhouse, 384 half sib families from the NCEDS $\mathrm{C}_{9}$ population were tested in the seedling stage for resistance to scab and anthracnose, and the most resistant plants transplanted for testing with powdery mildew. Themostresistant 346 plants were self pollinated to produce $\mathrm{S}_{1}$ lines. The $346 \mathrm{~S}_{1}$ lines were then tested in the seedling stage in the greenhouse for resistance to scab and anthracnose, and the most resistant plants transplanted for testing with powdery mildew. Simultaneously, the 346 $\mathrm{S}$ lines were tested in the field for gynoecy, dwarf-determinate habit, yield, earliness, and fruit quality. The lines with the best performance were then planted in the greenhouse to advance the materials to $\mathrm{S}_{9}$ inbred lines.

In 1999, hybrids were tested in the field using the best 7 gynoecious inbreds as female parents in crosses with the best 6 monoecious inbreds. A total of 13 hybrids were produced using pairs having complementary fruit length and other traits to get useful combinations. Hybrids and inbreds were tested in the field for gynoecy, dwarf-determinate habit, yield, earliness, and fruit quality. Inbreds of the hybrids with the best performance were then planted in the greenhouse to advance the materials to $\mathrm{S} 10$ inbred lines. The process was repeated in 2000. Finally, the top 4 hybrids were put into the cooperative trials for 2001, 2002, and 2003 (Tables 1 and 2).

Trials were run in the spring and summer production seasons using a randomized complete block design. Check cultivars were chosen to represent elite gynoecious hybrids and dwarf-determinate monoecious inbreds that have performed well over the years. They were 'Marketmore 85' in 2001, 'Dasher II' in 2002, and 'Dasher II', 'Intimidator', 'Cherokee',
'Poinsett 76', 'Marketmore 86', 'Marketmore 76', and 'Ashley' in 2003. Plots were harvested six times (twice weekly). Data were summarized over 3 replications, and 6 harvests for 2 crop production seasons (spring, summer) for 3 years (2001, 2002, 2003) at the Horticultural Crops Research Station near Clinton, N.C.

Data from the performance trials were presented for 9 to 10 major horticultural traits (Table 1). Total yield was the weight of marketable grades, oversized, and cull fruit summed over six harvests. Early yield was the percentage of the total weight in the first two harvests. Percentage culls was the weight of crooked and nubbin fruit relative to total fruit weight. The three major fruit quality traits presented were shape, color, and seedcell size. Fruit shape was rated 1 to 9 ( 1 to 3 = pointed, crooked, constricted; 4 to $6=$ tapered, curved, necked; 7 to $9=$ blocky, straight, cylindrical), and reflected how straight, uniform, and cylindrical the fruit in a plot were (Strefeler and Wehner, 1986). Fruit color was rated 1 to 9 ( 1 to $3=$ light green, 4 to $6=$ medium green, 7 to $9=$ dark green). Seedcell size was rated 1 to 9 ( 1 to $3=$ large, 4 to $6=$ medium, 7 to $9=$ small). Length and length:diameter ratio (LD) were measured using 3 grade 1 fruit per plot. Anthracnose and powdery mildew damage to the foliage (measured in summer only) was rated one week after the 6 th harvest $(0=$ none, 1 to $2=$ trace, 3 to $4=$ slight, 5 to $6=$ moderate, 7 to $8=$ severe, $9=$ dead). The diseases were naturally occurring in the trials since the spring trials were not sprayed with fungicides, and all trials had overhead irrigation to encourage anthracnose disease spread.

\section{Description}

The NC-58, NC-59, NC-62, and NC-63 inbreds, and 'NC-Stratford' and 'NC-Sunshine' hybrid slicing cucumbers have excellent horticultural characteristics, suitable for use by the fresh-market industry in the U.S. The inbreds and hybrids have medium-sized seeds, with rapid germination and emergence from either cool or warm soil. Vines have dwarf-determinate growth habit ('NC-Sunshine' has slightly shorter vines than 'NC-Stratford'), some lateral branching, and normal-sized, very dark-green leaves, with the crinkled leaf surface characteristic often found in the dwarf-determinate plant type. Plants are vigorous, with rapid growth, and flowers and fruit develop early in the vegetative growth stage. Sex expression is monoecious, with numerous flowers produced on the plants, beginning 30 days after planting. 'NC-Sunshine' is similar in percentage pistillate nodes to 'Dasher II', with 'NC-Stratford' slightly lower, with more pistillate flowers than 'Poinsett 76 ' or 'Spacemaster'.

Fruit color for NC-58, NC-59, NC-62, and NC-63 inbreds, and 'NC-Stratford' and 'NCSunshine' hybrid slicing cucumbers is uniform dark green. Fruit have few, large tubercles (warts), and are white spined. Fruit seedcell size of 'NC-Stratford' and 'NC-Sunshine' is small (subjective rating of 6 to 8 vs. 4 to 8 for the checks, where 1 is large and 9 is small).

'NC-Stratford' and 'NC-Sunshine' are resistant to the major disease problems in the southeastern U.S., ranked in importance by St. Amand and Wehner(1991). They are resistant to anthracnose (Colletotrichum orbiculare (Berk. \& Mont.)Arx), powdery mildew (Sphaerotheca fuliginea (Schlechtend.:Fr.) Pollacci), and scab (Cladosporium cucumerinum Ellis \& Arth.).

In addition to having dwarf-determinate plant type for easy fruit harvest, 'NC-Stratford' and 'NC-Sunshine' were better than (or at least as good as) the gynoecious hybrid checks for all traits relating to yield, earliness, fruit quality, and disease resistance (Table 1).

\section{Availability}

Seeds of the inbreds and hybrids are available to interested plant breeders who sign an intellectual property agreement. 'NC-Stratford' and its parental inbreds NC-58 and NC-59 werelicensed exclusively to Zeraim Gedera in 2004.

\section{Literature Cited}

Schultheis, J.R. 1990. Pickling cucumbers. N.C. State Agr. Ext. Hort. Info. Lflt. 14-A.

St. Amand, P.C. and T.C. Wehner. 1991. Crop loss to 14 diseases in cucumber in North Carolina for 1983 to 1988. Cucurbit Genet. Coop. Rpt. 14:15-17.

Strefeler, M.S. and T.C. Wehner. 1986. Estimates of heritabilities and genetic variances of three yield and five quality traits in three fresh-market cucumber populations. J. Amer. Soc. Hort. Sci. 111:599-605.

Wehner, T.C. 1982 . Weighted selection indices for trials and segregating populations. Cucurbit Genet. Coop. Rpt. 5:18-20.

Wehner, T.C. 1987. Efficient methods for testing vegetable cultivars. HortScience 22:1220-1223.

Wehner, T.C. 1989. Breeding for improved yield in cucumber, p. 323-359. In: J. Janick (ed.). Plant breeding reviews. vol. 6 .

Wehner, T.C., T.J. Monaco, and A.R. Bonanno. 1984. Chemical defoliation of cucumber vines for simulation of once-over harvest in small-plot yield trials. HortScience 19:671-673. 